\title{
The Foundations of the Internal Market: Free Trade Area and Customs Union under Articles 28-31 TFEU
}

\author{
Stefan Enchelmaier*
}

\begin{abstract}
This contribution places the provisions of the Treaty creating a free trade area and customs union between the Member States (Articles 28-31 TFEU) in their wider context. It then focuses on the interpretation of Article 30 in the jurisprudence of the Court of Justice of the European Union (CJEU). Throughout, it casts sideways glances at corresponding provisions of General Agreement on Tariffs and Trade (GATT). As it turns out, the abolition of customs duties and charges having equivalent effect, and the establishment of a customs union between Member States, were important milestones in the development of European unification. They became overshadowed later by more spectacular developments in the case law on the free movement of goods, persons and services. As a consequence, the importance of the customs provisions is widely underrated. Brexit concentrates the minds in this respect, as an important economy is about to rearrange and even recreate the basic building blocks of its international trading relations.
\end{abstract}

Keywords: free trade area, EU Customs Union, internal market, European Union, Brexit

\section{Introduction}

Articles 28 to 31 Treaty on the Functioning of the European Union (TFEU) are located at the very beginning of the Treaty's chapter on the four freedoms of the internal market. While Article 28(1) TFEU in the version of the Lisbon Treaty somewhat blandly says that the Union shall 'comprise' a customs union, the wording until 2009 was that Community shall be 'based upon' a customs union (Article 23 TEC). This formulation and its prominent position highlighted that the customs provisions had a fundamental importance, a pioneering function for the subsequent realisation of the other freedoms. Testimony to this is also the fact that the abolition of customs duties between Member States, and the establishment of the customs union vis-à-vis third countries, was accomplished for industrial prod-

Stefan Enchelmaier, Dr iur (Bonn) habil (Munich) LLM (Edinb) MA (Oxon) is Professor of European and Comparative Law at Lincoln College, University of Oxford. My thanks go to the anonymous reviewer, who suggested a number of helpful clarifications. ucts in mid-1968, well before the end of the transitional period on 31 December $1969 .^{1}$

The early start also meant that the most important legal questions were resolved early on. Since the period of the rapid unfolding of the case law between, roughly, 1968 and the mid-1970s, there were no more dramatic developments, but only incremental refinement. As a consequence, there are no controversies about the interpretation of the provisions that are not too obscure to warrant a discussion in the limited space available here. ${ }^{2}$ Related to this, Articles 28-31 are the wallflowers of the scholarship, and as it would seem, at least anecdotally, of academic teaching on the free movement of goods. The following offers reflections on the background and context of Articles 28-31, as well as a synthesis of the jurisprudence of the Court of Justice of the European Union (CJEU) regarding their interpretation.

This sounds like a moderate ambition. It derives its relevance, however, from the impending departure (barring some unforeseen and tumultuous development in the meantime) of the United Kingdom from the European Union (EU). One important desire of those promoting 'Brexit' is to regain for 'Global Britain' the freedom to

1. The schedule for abolition of customs duties between Member States, and for the establishment of the common customs tariff, was last contained in Arts 7 and 14-24 EC after the 1992 Maastricht amendments, then removed by the amendments following the 1997 Treaty of Amsterdam.

2. Some commentaries and textbooks covering Arts 28-30 TFEU are: Arnull and Chalmers, The Oxford Handbook of European Union Law, 2015; Barnard, The Substantive Law of the EU, 6th ed. 2019; Barnard and Peers, European Union Law, 2nd ed. 2017; Calliess and Ruffert, EUV/AEUV, 5th ed. 2016; Chalmers, Davies \& Monti, European Union Law, 3rd ed. 2014; Craig and de Búrca, EU Law. Text, Cases, and Materials, 6th ed. 2015; Dashwood, Dougan, Rodger, Spaventa \& Wyatt, Wyatt and Dashwood's European Union Law, 6th ed. 2011; Dauses and Ludwigs, Handbuch des EU-Wirtschaftsrechts, loose-leaf, last updated January 2019; Ehlermann, Bieber \& Haag, Handbuch des Europäischen Rechts, loose-leaf, last updated March 2019; Geiger, Khan \& Kotzur, EUVIAEUV, Vertrag über die Europäische Union und Vertrag über die Arbeitsweise der Europäischen Union, 6th ed. 2017; Gormley, EU Law of Free Movement of Goods and Customs Union, 2009; Grabitz, Hilf \& Nettesheim, Das Recht der Europäischen Union, 3 vols, loose-leaf, last updated June 2019; v.d. Groeben, Schwarze \& Hatje, Kommentar zu EUV, AEUV und GRCh, 4 vols, 7th ed. 2015; Kilian/Wendt, Europäisches Wirtschaftsrecht, 6th ed. 2017; Lyons, European Customs Law, 2018; Pechstein, Nowak \& Häde, Frankfurter Kommentar zu EUV, GRC und AEUV, 2017; Schwarze, Becker, Hatje \& Schoo, EU-Kommentar, 4th ed. 2019; Streinz, EUV/AEUV, Kommentar, 3rd ed. 2018; Weatherill, Cases \& Materials on EU Law, 12th ed. 2016, all with further references to specialist literature. 
stride out into the world and conclude trade agreements with any countries it likes, on terms that it chooses, without being hemmed in by the political and legal compromises that the UK had to accept in this respect as a Member State of the EU. Many of the claims made in this respect, however, turn out to be fantastical because they are devoid of even a basic understanding of the concepts fundamental to international trade in general, and intra-EU trade in particular. These concepts are: free trade area, customs union and internal market. They will first be explained in the following, before the interpretation of Article $30 \mathrm{TFEU}$ is brought into focus.

\section{The Stages of Economic Integration in the Internal Market}

The context of the prohibition of customs duties and charges having equivalent effect is the creation of the internal market, described in Article 26(2) TFEU as an 'area without internal frontiers' to the free movement of goods, persons, services and capital (the 'four freedoms'). The economic integration between the Member States thus covers all sectors of their economies. From the perspective of the four freedoms, the Member States are seen as markets, and as the several legal systems that govern economic transactions taking place on each of these markets.

In order to integrate the national markets, the Treaty tackles different kinds of 'frontiers', all understood as legal obstacles to economic exchange across the persisting political and geographical borders. The most fundamental distinction is that between financial (or tariff-) ${ }^{3}$ barriers and non-financial (or technical) barriers to trade. The Treaty articles discussed below contribute to the dismantling of fiscal barriers; that is, they bring about financial neutrality in trade between Member States.

Transport costs will inevitably increase as goods are shipped farther afield, especially into other Member States. This cannot be helped by any sort of legal rules. Nevertheless, the fiscal burdens on transactions crossing the borders to and from other Member States (i.e. those burdens imposed by national law, rather than those arising naturally from geographical distance) must not be graver than those taking place within one and the same Member State. ${ }^{4}$

3. The Court, largely synonymously, uses the term 'fiscal' barriers. This places somewhat more emphasis on the origin of the barrier in a demand for payment made under public law by a Member State, or by a body authorised by the state to collect money from exporters or importers.

4. Case C-206/06 Essent Netwerk Noord, ECLI:EU:C:2008:413, para. 60: 'Articles [30 and 110 TFEU] seek to preserve the free movement of goods and competition between domestic products and imported products.'
The Court, accordingly, sees two justifications for the prohibition of customs duties and charges having equivalent effect: first, they artificially increase the price of imported or exported goods in relation to domestic products; ${ }^{5}$ secondly, the free movement of goods is further aggravated by the resulting administrative formalities. $^{6}$

Financial- and non-financial barriers are not only conceptually distinct but they also stand for different modes of integration coexisting under the Treaty: free trade area, customs union, internal market. ${ }^{7}$ These can be described as 'layers', to capture their simultaneous pursuit by the Treaty. In this view, Articles 28-30 would appear as the most basic: a simple prohibition without exceptions and, correspondingly, no need (or even possibility) to adopt harmonising legislation: ${ }^{8}$ national customs duties and charges having equivalent effect become illegal and, eventually, simply disappear. Alternatively, one can speak of 'stages' of integration to emphasise that they have historic precursors and were (and still are) realised to varying extents at different times, in and between different countries.

A free trade area, at its simplest, involves no more than the reduction or even abolition of customs duties and of quantitative restrictions. ${ }^{9}$ In the EU, this is the task of Articles 28(1) and 30 - adding a prohibition of charges having equivalent effect to customs duties - as well as of the first alternative of Article 34. ${ }^{10}$ The promise to liberalise trade is made, however, only between the participating states, not to (or with regard to) third countries. The participating states remain free to adopt independ-

5. Case C-209/89 Commission v. Italy (Out of hours-fees), ECLI:EU:C: 1991:139, para. 7; Case C-65/16 Istanbul Lojistik, ECLI:EU:C: 2017:770, para. 39.

6. Cases 63/74 Cadsky, ECLI:EU:C:1975:33, para. 4; 46/76 Bauhuis, ECLI:EU:C:1977:6, para. 9; C-389/00 Commission v. Germany (Solidarity fund), ECLI:EU:C:2003:111, para. 22; C-254/13 Orgacom, ECLI:EU:C:2014:2251, para. 22; C-5/14 Kernkraftwerke Lippe-Ems, ECLI:EU:C:2015:354, para. 87.

7. (Economic and) Monetary union may be added, but will be left out of consideration in the text above, not least because not all Member States have adopted the common currency.

8. This simplification is not meant to deny that quantitative restrictions (quota) are not governed by Articles $28-30$ but by Articles 34 and 35 and that they are therefore capable of justification under Article 36, which is unavailable for charges that come under Article 30: Cases C-441/98 Mikhaïlidis, ECLI:EU:C:2000:479, para. 14; C-173/05 Comission v. Italy (Gas pipelines), ECLI:EU:C:2007:362, para. 42; Istanbul Lojistik (n5), para. 41.

9. See the definition in GATT 1947/1994 (full text under https:// www.wto.org/english/docs_e/legal_e/gatt47_01_e.htm), Art. XXIV(8) (b): 'A free-trade area shall be understood to mean a group of two or more customs territories in which the duties and other restrictive regulations of commerce .... are eliminated on substantially all the trade between the constituent territories in products originating in such territories.'

10. Similarly under GATT 1947/1994 (n9), Art. XI(1), 'No prohibitions or restrictions other than duties, taxes or other charges, whether made effective through quotas, import or export licences or other measures, shall be instituted or maintained by any contracting party on the importation of any product of the territory of any other contracting party or on the exportation or sale for export of any product destined for the territory of any other contracting party', and duties shall be reduced through negotiations pursuant to Art. II, with the reductions conceded to the most favoured nation to be extended, in principle, to all other contracting parties, Art. I(1). 
ent trade policies vis-à-vis third countries. As a consequence, third countries' traders who want to market their goods in a participating state with high tariffs will route their products through the participating state with the lowest possible tariffs. (The cost of transport to the target state from the state with the lowest tariff in absolute terms might be prohibitive.)

Because separate and different external tariffs remain permissible to the participants in a free trade area, each state is within its rights to defend its chosen tariffs on imports from third countries. A free trade area will therefore need rules of origin to determine which goods benefit from the mutual promises and which do not. These rules will need policing, implemented through border controls. Trade between the states participating in a mere free trade area will, therefore, never be entirely free: the financial barriers may be gone, but not the physical ones. The most important contemporary example of a mere free trade area is the one between the USA, Mexico and Canada.

Border controls are needed, as we have seen, to patrol separate, national external tariffs. These controls become redundant if there are no longer any such tariffs. The next step up in economic integration is, hence, the adoption of one set of tariffs that applies to all participating states in their trade with third countries. Once the countries of the free trade area have adopted such a single tariff, they form a customs union. ${ }^{11}$ This makes rules of origin redundant and shifts all necessary financial controls to the external borders of the participating states, removing them from the borders between them. ${ }^{12}$ An historic example of a customs union is the German Zollverein of 1834; currently, there exists only one permanent customs union between sizeable, developed countries, namely the EU. ${ }^{13}$ In the EU, a customs union is realised by the adoption of the Common Customs Tariff on the basis of Article 31 TFEU.

Even in a customs union, however, trade is not entirely free. This is because only financial restrictions and quota are addressed. The next step up from a customs union is, therefore, the reduction or abolition of the much more numerous non-financial barriers. This leads to the creation of an internal market. As far as goods are concerned, the EU seeks to achieve this aim through the prohibition of measures having equivalent effect to quantitative restrictions on imports, exports and goods

11. See the definition in GATT 1947/1994 (n9), Art. XXIV(8)(a): 'A customs union shall be understood to mean the substitution of a single customs territory for two or more customs territories ...'

12. Similarly to what the Court found in n4, it held with regard to the Common Customs Tariff that the latter 'is intended to achieve an equalisation of customs charges levied at the borders of the Community on products imported from non-member countries, in order to avoid any [deflection of trade in relations with those countries and] distortion of free internal circulation or of competitive conditions', Case 266/81 SIOT, ECLI:EU:C:1983:77, para. 18; without the text in square brackets, but otherwise identical in Gas pipelines (n8), ECLI:EU:C:2007:362, para. 29.

13. The customs union between Turkey and the EU is meant to be a staging post on Turkey's way to eventual membership of the EU; as this prospect (currently) fades, that customs union becomes more durable than originally envisaged. in transit, Articles 34-36, and harmonising EU legislation adopted under Article 114 TFEU.

The geographical reach of the internal market between the Member States is extended by the European Economic Area (EEA) Agreement. Under this agreement, the EU grants the European Free Trade Association (EFTA) states, Iceland, Liechtenstein and Norway, access to its single market, and the latter reciprocate by allowing access to their markets and by making financial contributions. ${ }^{14}$ They do not, however, participate in the political integration of the single market, i.e. in the creation of harmonised or uniform supranational law for the internal market. There is also no customs union between the EU and non-EU EEA states. ${ }^{15}$

Against this background, Article 30 stands out as the bedrock of economic integration in the EU. Most of the fundamental questions pertaining to its interpretation came before the Court of Justice between the late 1960s and the mid-1970s. Since then Articles 34, 45, 49, 56 and 63 TFEU have overtaken it in terms of attention, as manifested in the number of cases that come before the Court. Nevertheless, as much as the realisation of Article 30 was the first step towards the internal market, the provision will remain applicable to goods imported into the EU, and then moving between Member States, from the post-Brexit UK.

\section{The Scope of Article 30 TFEU}

The provisions of the Treaty that are relevant here, Articles 28-30 TFEU, open the title on 'Free movement of goods'. Article 28 stipulates, accordingly, that the customs union 'shall cover all trade in goods'. The first question when clarifying the scope of the provision is, therefore, the meaning of 'goods'. The Court of Justice of the European Union (the Court) defined goods as physical objects that can be valued in money and that can be the subject of commercial transactions. ${ }^{16}$

The origin of the goods is immaterial. Article 30 applies without further to goods made, assembled or refined in the Member States. Article 28(2) extends the benefit of Articles 30-37 TFEU ('Chapter 3 of this Title') to goods coming from third countries that are in free circulation in Member States. Article 29 defines when goods are in free circulation, viz. when they have undergone customs clearance in accordance with the Common

14. Apart from their financial contribution to the EU budget, see https:// eeagrants.org for a list of programmes financed directly by Iceland, Liechtenstein and Norway in poorer EU Member States.

15. For a brief overview of the contents of the EEA Agreement, see www.efta.int/eea/eea-agreement/eea-basic-features\#1.

16. Case 7/68, Commission v. Italy (Art treasures), ECLI:EU:C:1968:51, p. 428 of the English version of the European Court Reports. Nevertheless, electricity is also covered, Essent Netwerk Noord (n4), para. 40, and the categorisation as 'goods' is independent of the intrinsic value of the goods: even waste shipped for disposal is encompassed by the concept of goods, Case C-221/06 Frohnleiten, ECLI:EU:C:2007:657, paras. 37,38 
Customs Tariff. An example of goods in free circulation can be found in the seminal case on Article 34, Dassonville, ${ }^{17}$ concerning Scotch Whiskey. Articles 28(2) and 29 will come to renewed prominence following the departure of the United Kingdom from the EU.

The shift in the wording between 'goods' in Article 28(1) to 'products' in Articles 28(2) and 29 and back to 'goods' in Article 36 has no substantive consequences. As Article 32(c) indicates, the free movement of goods is concerned with raw materials as well as with semi-finished and finished goods.

The prohibition of Article 30 applies to 'customs duties and charges having equivalent effect'. A customs duty is simply any demand for payment that is labelled a customs duty, made on the occasion of goods crossing a frontier between Member States. ${ }^{18}$ More conceptual sophistication is not required: all other dues can (Article 110 notwithstanding) still be charges having equivalent effect to customs duties. This complementarity between the two concepts is meant to prevent any gaps in the removal of financial barriers to trade between Member States. ${ }^{19}$

The Court developed the definition of 'charges having equivalent effect to customs duties' in its judgement in an action brought by the Commission against Italy. That Member State had imposed a levy on all goods crossing its frontiers in either direction. The money was said to be the quid pro quo for making customs statistics compiled by the Italian authorities available to importers and exporters. ${ }^{20}$ The statistics purportedly allowed these traders 'to determine precisely the actual movements of goods and, consequently, changes [in] the state of the market'. The exactness of the information, moreover, 'afford[ed] importers a better competitive position in the Italian market whilst exporters enjoy[ed] a similar advantage abroad'. ${ }^{21}$ As a consequence, the Italian government argued, the levy did not constitute a charge having equivalent effect to a customs duty.

17. Case 8/74 Procureur du Roi v. Benoît and Gustave Dassonville, ECLI:EU:C:1974:82

18. This follows a contrario from the element 'whatever its designation' in the Court's definition of a charge having equivalent effect to a customs duty (below d)): if a monetary burden is not called ('designated') a customs duty, it will be a charge having equivalent effect (provided the other elements of the definition are also present).

19. Joined Cases 2/69 and 3/69 Diamantarbeiders, ECLI:EU:C:1969:30, paras. 15-18: 'The extension of the prohibition of customs duties to charges having equivalent effect is intended to supplement the prohibition against obstacles to trade created by such duties by increasing its efficiency. The use of these two complementary concepts thus tends, in trade between member states, to avoid the imposition of any pecuniary charge on goods circulating within the [EU] by virtue of the fact that they cross a national frontier'; likewise in Case 87/75 Bresciani ECLI:EU:C:1976:18, para. 8/9.

20. The Italian government here invoked, in so many words, what it would have been allowed to do under Art. VIII of GATT 1947/1994 (n9): '4 The provisions of this Article shall extend to fees, charges, formalities and requirements imposed by governmental authorities in connection with importation and exportation, including those relating to: ... (e) statistical services; ...'

21. Case 24/68 Commission v. Italy (Statistical levy), ECLI:EU:C:1969:29, para. 15.
The Court found otherwise based on its understanding of a charge having equivalent effect:

any pecuniary charge, however small and whatever its designation and mode of application, which is imposed unilaterally on domestic or foreign goods by reason of the fact that they cross a frontier, and which is not a customs duty in the strict sense, constitutes a charge having equivalent effect within the meaning of [Article $30 \mathrm{TFEU}$ ], even if it is not imposed for the benefit of the state, is not discriminatory or protective in effect and if the product on which the charge is imposed is not in competition with any domestic product. $^{22}$

The elements of this definition will be successively elucidated below.

\section{4 'Any Pecuniary Charge'}

The emphasis in this first element of the definition is on 'any', to which the Court adds, 'however small'. In other words, the amount demanded is immaterial. It is ultimately the administrative formalities entailed by its collection that hinder trade. ${ }^{23}$ Such hindrance goes against the very idea of the internal market as 'an area without internal frontiers in which the free movement of goods ... is ensured', as Article 26(2) TFEU puts it. ${ }^{24}$ The detrimental effect on trade also explains why Article 30 applies likewise to para-fiscal charges, that is, those paid under a legal obligation to a private or autonomous public body. ${ }^{25}$

Articles 34 and 35 TFEU (the prohibition of quantitative restrictions and measures having equivalent effect), by contrast, apply to non-pecuniary burdens, that is, (typically) to controls. In practice, these burdens ought to be assessed first: if the controls are illegal, so must the charges therefor be. (If the control is permissible, the charge is still lawful only if it constitutes taxation; see below. $)^{26}$

22. Statistical levy (n21), para. 9; see, most recently, Cases C-76/17 Petrotel-Lukoil, ECLI:EU:C:2018:139, para. 21; C-39/17 Lubrizol France, ECLI:EU:C:2018:438, para. 24.

23. See in and by $n 6$.

24. Case 132/82 Commission v. Belgium (Customs warehouses), ECLI:EU:C:1983:135, para. 9: 'The prohibition of charges having an effect equivalent to customs duties, laid down in provisions of the Treaty, is justified on the ground that pecuniary charges imposed by reason or on the occasion of the crossing of the frontier represent an obstacle to the free movement of goods.'

25. Case 94/74 Industria Gomma Articoli Vari (IGAV), ECLI:EU:C:1975:81, para. 11: 'the fact that a duty is levied by an independent institution governed by public law rather than levied by the state itself and is used by that institution for purposes intended by the relevant legislation involves no difference with regard to the possible definition of that fiscal charge as a charge having an effect equivalent to customs duties, since the prohibition under Article [30, 2nd sentence] attaches solely to the effect of such charges and not to the manner in which they are imposed'; Essent Netwerk Noord (n4), para. 46: charge payable to the operators of networks for the distribution of electricity.

26. Case 32/80 Kortmann, ECLI:EU:C:1981:20, paras. 11, 12. For an example, see Case 158/82 Comission v. Denmark (Groundnuts), ECLI:EU:C: 


\section{5 'Imposed'}

The charge must be 'imposed', that is, authoritatively and unconditionally demanded.

An authoritative and unconditional demand implies that there is compulsion brought to bear on the importer or exporter. This element of compulsion is absent where the charge is 'consideration for a service actually rendered'. ${ }^{27}$ This in turn requires a specific benefit for individual traders. In fact, however, the case law does not contain a single example of the Court's finding 'services' to have been 'actually rendered', and the trader having paid therefor in discharge of a contractual obligation voluntarily undertaken. This element of the definition is in reality mere lip service, a polite put-down of the Italian government's defence in Statistical levy. The involuntary and inescapable nature of the situation in which the 'service' is rendered (and payment demanded) excludes its counting as a 'benefit'. The Court quotes the 'consideration ...' formula as often (namely, every time) as it finds that the traders in question have not received any service that could prevent their payment in return for being qualified as a charge having equivalent effect to a customs duty.

Nevertheless, just to be certain one might want to run through the test as set out by the Court. The first question is whether the trader(s) have received a 'benefit'. This translates into whether they would otherwise have procured the service on the open market, voluntarily rather than nolens volens. This will never be the case where the trader(s) merely took up whatever relief the customs authorities or others on their behalf offered while the traders complied with any import formalities. ${ }^{28}$ No benefit is market access itself: this is every importer's and exporter's right under the Treaty, which

1983:317, where the health inspections in issue were legal, but the way they were financed amounted to charges having equivalent effect to customs duties.

27. Statistical levy (n21), para. 11; Solidarity fund (n6), para. 23. - The wording is apparently gleaned from Art. II of GATT 1947/1994 (n9): '2. Nothing in this Article shall prevent any contracting party from imposing at any time on the importation of any product: ... (c) fees or other charges commensurate with the cost of services rendered' (emphasis added). Only once products have been imported is it that they, 'shall not be subject, directly or indirectly, to internal taxes or other internal charges of any kind in excess of those applied, directly or indirectly, to like domestic products.'

28. See, e.g., Customs warehouses (n24), para. 13: 'Whilst it is true that the use of a public warehouse in the interior of the country offers certain advantages to importers it seems clear first of all that such advantages are linked solely with the completion of customs formalities which, whatever the place, is always compulsory. It should moreover be noted that such advantages result from the scheme of Community transit, .. in order to increase the fluidity of the movement of goods and to facilitate transport within the [EU]. There can therefore be no question of levying any charges for customs clearance facilities accorded in the interests of the common market', and similarly in Case C-16/94 Dubois, ECLI:EU:C:1995:268, para. 18. For another vivid illustration, see Case 39/82 Donner, ECLI:EU:C:1983:3, para. 11: '[T] he postal administration's argument to the effect that a private individual may refuse to accept delivery, send the postman and the parcel away and make a declaration himself which would entail cancelling the declaration already made by the postal administration, would seem to ignore the realities of daily life. they can vindicate in the national courts. ${ }^{29}$ It is not a privilege granted at whim by the Member State, and as easily denied or withdrawn by that state.

If there is a benefit at all, it must be 'specific', i.e. measurable. It must be possible to attach an approximate monetary figure to it. ${ }^{30}$ The charge must be in proportion to that figure. The criteria for gauging the proportionality of the consideration can be gleaned from the limits that apply to the extent to which Member States may recoup administrative expenses for mandatory inspections (see below). Whether the Member State, or an authorised private organisation acting on its behalf, can be allowed a profit margin on top will have to be assessed under the EU rules on state aid and on public procurement; here is not the place for a detailed discussion.

The specific benefit must finally also be 'individual'. It must accrue to one or several traders in and because of the circumstances in which they find themselves. It is not enough that they come to enjoy the benefit only as a member of a group. ${ }^{31}$ (One might think, by way of analogy, of a movie shown on an overhead monitor during the flight on a plane: this is not shown to any one individual passenger, but to all in the round.) Equally insufficient is a benefit to the general public, as in the case of health checks. ${ }^{32}$ Such controls must be financed out of general taxation. Their costs cannot be rolled over to traders. Individual traders might well be spared liability for any faulty products that had been spotted during controls. This is, however, a mere reflex, and sufficiently remunerated by the traders' contributing to the general tax revenue.

\section{6 'Unilaterally by a Member State'}

The element of the definition that asks whether the charge has been imposed unilaterally by a Member State translates into the question of whether any controls for which the charge was levied are mandatory under EU

29. Joined cases C-277/91, C-318/91 and C-319/91 Ligur Carni, ECLI:EU:C:1993:927, para. 39.

30. Cadsky (n6), para. 6

31. See, e.g., Statistical levy (n21), para. 16: 'The statistical information in question is beneficial to the economy as a whole and inter alia to the relevant administrative authorities. Even if the competitive position of importers and exporters were to be particularly improved as a result, the statistics still constitute an advantage so general, and so difficult to assess, that the disputed charge cannot be regarded as the consideration for a specific benefit actually conferred'; and Cadsky (n6), para. 8: 'Even if the maintenance of the reputation of fruit and vegetable products of a member state by the indirect expedient of a certificate of inspection and the affixing of a national export stamp is capable of encouraging exports of national products, this benefit relates to the general interest of all exporters, so that the individual interest of each of them is so ill-defined that a charge imposed in payment for this inspection cannot be regarded as consideration for a specific benefit actually and individually conferred'; Solidarity fund (n6), para. 36

32. Bresciani (n19), para. 10. 
law. ${ }^{33}$ If the Member States must, under EU law, carry out the controls, they may recoup their administrative expenses, and it does in that regard not matter for the legality of each Member State's charges that some Member States have decided not to recoup the expenses from traders, but to finance them out of general revenue. ${ }^{34}$ Once the products have passed muster, they can move throughout the internal market without any repetition of the same controls. These charges, therefore, do not hinder free trade but enable it. They give all Member States into which the product is imported subsequently the confidence that it has been tested in accordance with common rules. What is more, all Member States have participated in the adoption of these rules by the EU's legislative institutions. If Member States 'went it alone', the number of controls would inevitably multiply, and free trade would become illusory.

Nevertheless, if a Member State has legitimately decided to finance the controls through fees levied on traders, these fees must not yield a profit for the Member State. ${ }^{35}$ There must, in other words, be a direct link between the charge and the costs that the Member State has incurred for the controls. ${ }^{36}$ This element in the Court's jurisprudence is an echo of the general principle of proportionality, applicable whenever the Member States implement EU law: the financial burden imposed on a trader by a Member State must not go further than is necessary for the Member State's complying with its obligations under EU law.

Permissible criteria for calculating the fees are, therefore, the duration of the inspection; the cost of the materials used therein; overheads such as the upkeep of buildings, test equipment, fuel and energy; the salaries of the personnel deployed for the checks. Impermissible is, accordingly, a calculation based on the price or value of the goods: ${ }^{37}$ these parameters have no influence on the actual costs of the inspection.

The charging of a fixed rate is permissible, as long as it is in keeping with the principle of proportionality. Member States may, thus, demand a single price for the performance of a specific task, no matter how long it takes to perform that task in an individual case. Likewise, if calculation of the fee is by time spent on a given job, Member States may round up to the full hour (or another convenient unit of time).

Nevertheless, even in such cases of permissible generalisation, the ultimate fee must approximately reflect the costs that the controls have occasioned. That makes a cumulation of generalisations problematic. The necessary proximity is left behind, for instance, where a Member State performs one and the same task simultaneously for several traders (the inspection of a combined con-

\footnotetext{
33. Solidarity fund (n6), para. 23; Lubrizol France (n22), para. 26.

34. Solidarity fund (n6), para. 39.

35. Bauhuis (n23), paras. 31, 36

36. Case C-111/89 Bakker Hillegom, ECLI:EU:C:1990:177, para. 12; Solidarity fund (n6), para. 40

37. Bakker Hillegom (n36), paras. 13, 14
}

signment, say), rounds up the time taken and charges the full amount to each of the traders. ${ }^{38}$

This has to be distinguished from the situation that controls are merely permitted by EU law, rather than mandatory under it: such optional controls have to be financed out of general taxation, not by the traders. ${ }^{39}$ In other words, Member States may charge traders for such controls only if the payments demanded from traders constitute taxation as defined below. ${ }^{40}$

\section{7 'On Imported/Exported Goods for the Sole Reason That They Cross a Frontier'}

This element of the definition serves to delineate the scope of application of Article 30 and Article 110 TFEU, respectively: there is no charge having equivalent effect to a customs duty where the payment demanded is part of a system of internal taxation under Article $110 .^{41}$

Charges having equivalent effect are characterised by the fact that they one-sidedly encumber goods coming from or going to other Member States, for the sole reason that these goods have crossed, or are about to cross, a frontier. The Court, in the name of a 'general principle of freedom of transit of goods within the European Union', interprets Article 30 also to capture obligatory payments due when a product enters into or leaves a subdivision of a Member State from or for another such subdivision. ${ }^{42}$

None of the national measures in issue in those cases, however, drew a distinction between imports from other regions of the same Member State, on the one hand, and from other Member States, on the other hand; nor between exports to other regions of the same Member State and those to other Member States. It is therefore not clear why it should not have been possible to deal adequately with these situations under Article 110 .

38. Out of hours-fees (n5), paras. 13-16.

39. Ligur Carni (n29), paras. 30, 31. In this respect, the Member States' duty to abstain from demanding any payment from traders for 'unilateral' controls goes further than their obligation under GATT (n9), which allows such charges in Art. VIII(1)(a): 'All fees and charges of whatever character (other than import and export duties and other than taxes within the purview of Article III) imposed by contracting parties on or in connection with importation or exportation shall be limited in amount to the approximate cost of services rendered and shall not represent an indirect protection to domestic products or a taxation of imports or exports for fiscal purposes.

40. Kortmann (n26), paras. 16-18

41. Case 78/76 Steinike \& Weinlig, ECLI:EU:C:1977:52, para. 27; Case 132/78 Denkavit Loire, ECLI:EU:C:1979:139, para. 7; Comission v. Denmark (Groundnuts) (n26), para. 21; Case C-402/14 Viamar, ECLI:EU:C:2015:830, para. 33; Lubrizol France (n22), para. 25.

42. For imports, see Case C-363/93 et al. Lancry, ECLI:EU:C:1994:315, paras. 25-31; for exports, Case C-72/03 Carbonati Apuani, ECLI:EU:C: 2004:506, paras. 18, 22-26; Case C-293/02 Jersey Produce Marketing, ECLI:EU:C:2006:403, paras. 62-64; for goods in transit, Gas pipelines (n8), paras. 30-33; most recently Orgacom (n6), paras. 24, 25; Istanbul Lojistik (n5), para. 42 
There may well exist the general principle that the Court has identified. Conspicuously, however, the Treaty itself alludes to it in Article 36 TFEU (listing grounds of justification for quantitative restrictions and measures having equivalent effect), ${ }^{43}$ not in the provisions concerning financial obstacles to trade. Despite their differences, the provisions of Articles 30 and 110 are complementary to one another: ${ }^{44}$ crucially, that means that there is no gap between them that needs filling in by the said general principle.

The concept of 'taxation' is wide: it encompasses all financial dues that apply to categories of products according to abstract criteria, that is, irrespective of the destination (in case of exports) or origin (imports) of the products. ${ }^{45}$ This is so even if there are no comparable domestic products, ${ }^{46}$ never mind that the first paragraph of Article 110 cannot apply to them in the absence of a domestic equivalent (but instead the second paragraph can). ${ }^{47}$ By contrast, the different repercussions of the financial burden on different types of producers or traders are irrelevant. It does not matter, for instance, that parallel traders, dealing in smaller quantities of a larger number of different products, are hit harder by fixed annual authorisation fees than 'official' distributors who achieve high turnover with a small number of different products. ${ }^{48}$ Likewise, it is immaterial if consumers ultimately bear the charge. ${ }^{49}$

It is not clear, however, what the Court means by 'categories' of products to which a financial burden must apply for it to be classified as a tax rather than as a charge having equivalent effect. In a case in which a Member State had imposed a charge on a group of products comprising three types of nuts, it found that such a limited number of products could not fall within the concept of 'whole classes of ... products' ${ }^{50}$ For that to be the case, a 'much larger number of products deter-

43. The Court pointed to the inclusion of transit in that provision in SIOT (n12), para. 16

44. See in and by n19, and also Statistical levy (n21), paras. 4, 5; Case 193/85 Co-Frutta, ECLI:EU:C:1987:210, para. 27; Case C-393/04 Air Liquide, ECLI:EU:C:2006:403, para. 55; Essent Netwerk Noord (n4), para. 40; Frohnleiten (n16), para. 30.

45. Denkavit Loire (n41), para. 7; Comission v. Denmark (Groundnuts) (n26), para. 21; Diamantarbeiders (n19), paras. 19/21; most recently, Orgacom (n6), para. 29; Lubrizol France (n22), para. 24.

46. Case 27/67 Fink-Frucht, ECLI:EU:C:1968:22, [1968] ECR Eng. Spec. Ed. 223, 231, 2nd para: 'Article [110 TFEU] is intended to remove certain restrictions on the free movement of goods. But to conclude that it prohibits the imposition of any internal taxation on imported goods which do not compete with domestic products would be to give it a scope exceeding its purpose. Internal taxes, and turnover tax in particular, are essentially fiscal in purpose. There is therefore no reason why certain imported products should be given privileged treatment because they do not compete with any domestic products capable of being protected'; likewise, Steinike \& Weinlig (n41), para. 30; Case C-383/01 Danske Bilimportører, ECLI:EU:C:2003:352, para. 35; Kernkraftwerke Lippe-Ems (n6), para. 90.

47. Danske Bilimportører (n46), para. 38; Viamar (n41), para. 36

48. Kortmann (n26), paras. 27, 28

49. Essent Netwerk Noord (n4), para. 49

50. The Court in Steinike \& Weinlig (n41), para. 30, spoke of 'whole classes of domestic or foreign products which are all in the same position no matter what their origin'. mined by general and objective criteria' were required. ${ }^{51}$ That would leave the national court guessing, 'how long is a piece of string?' The inclusion of domestic products alone cannot be decisive, either. Otherwise imported products would find themselves at a disadvantage, contrary to the case law just cited, ${ }^{52}$ simply because of the happenstance that there is no domestic competing product.

The question should rather be whether any products are left out of the national categorisation although they share the characteristic(s) that lead to the inclusion of the few (in casu, the characteristic was the possible presence of a toxic pollutant). That characteristic must, moreover, sufficiently distinguish that group from other groups that raise similar concerns (with regard to human health, for instance). In essence, this test is a discrimination assessment. The same idea can also be expressed in terms of proportionality, namely as the question whether the differences between the products that are included and those that are not are large enough to warrant the difference in treatment.

The next question to ask in order to distinguish taxes from charges having equivalent effect is whether the same chargeable event, at the same marketing stage, gives rise to the duty. ${ }^{53}$ If there is no domestic competition (because, say, a country has no car industry), the question becomes whether the chargeable event took place at all: for example, registration of cars, for which Greece collected a charge on importation, even if the cars were immediately re-exported to other Member States rather than registered in Greece. ${ }^{54}$

Examples of unequal chargeable events are supply to the consumer in the case of imports, but commencement of use by the consumer in the case of domestic products; $;{ }^{55}$ of different marketing stages, the slaughter of pigs in the case of domestic products, and the marketing of lard in the case of imports. ${ }^{56}$ Release onto the domestic market, by contrast, marks the same event for domestic as well as imported products: for the former, it occurs at the factory gate; for the latter when they cross the border. ${ }^{57}$ Another example of the same event is the sale of goods on the national territory, and the transfer to another Member State of goods with a view to their sale, but not their transfer to another Member State for a purpose other than sale, ${ }^{58}$ say, for use in a foreign subsidiary. The same event - withdrawal from the national herd or release from national primary production - is the

51. Groundnuts (n26), para. 24

52. See in and by $n 46$.

53. Denkavit Loire (n41), para. 8; Mikhaïlidis (n8), para. 23; Case C-234/99 Nygård, ECLI:EU:C:2002:244, para. 20; Petrotel-Lukoil (n22), para. 24; Lubrizol France (n22), para. 39.

54. Viamar (n41), para. 45.

55. Case C-109/98 CRT, ECLI:EU:C:1999:199, paras. 13-15.

56. Denkavit Loire (n41), para. 8: Member States must not seek to equalise burdens borne by domestic products at earlier stages of production or marketing, such as the contributions paid by domestic producers for the maintaining of hygiene standards in domestic abattoirs; Mikhaïlidis (n8), para. 23.

57. Case C-68/96 Grundig Italiana (no.1), ECLI:EU:C:1998:299, paras. 15, 16.

58. Lubrizol France (n22), paras. 42, 43. 
slaughter of domestically reared animals and the exportation of live animals. ${ }^{59}$

If the chargeable event and the marketing stage are the same, it is a question for Article 110 whether the amount to be paid is the same. The methods of calculation and collection must also be the same, unless it is established that the charge to tax on the imported product remains at all times the same as or lower than the charge applicable to the similar domestic product. ${ }^{60}$ If the tax is lawful in either of these cases, it does not matter that it is the producer who is subject to the financial burden in the case of domestic products, while the traders have to bear it for imported products, ${ }^{61}$ nor that they are payable to separate authorities. ${ }^{62}$ Charges levied in the Member State of origin need not, however, be deducted, cf. Article 111 TFEU. ${ }^{63}$

Even if the above conditions a)-d) for a charge to be classified as taxation are fulfilled, the situation will still be governed by Article 30 on two conditions. First, the revenue of the tax is used to confer a measurable advantage on the (identical) domestic product when it is put on the market. ${ }^{64}$ The benefit can be conferred indirectly, as when the costs of past investments made by the domestic producers are taken into consideration by the (quasipublic) distributors when establishing the purchase price, but these costs are already defrayed by the levy on all products of that type, including imported. ${ }^{65}$ Secondly, the tax burden of the domestic product is offset in total. ${ }^{66}$

Within the limits set for state aids by Articles 107 et seqq. TFEU, it does not matter whether the benefits accrue to the supply side (producers) or to the demand side of the market (consumers). If consumers are the beneficiaries, there must be a direct obligation or an indirect enticement to buy domestic rather than imported products.

If, by contrast, consumers' choice is free, the charge is not incompatible with Article 30. If, say, computer equipment for use in schools were the subject of such a neutral incentive scheme, there might still be long-term advantages to the national economy in the form of a more productive workforce. Such advantages would not, however, accrue specifically to the competing domestic product at the time when it is put on the market but to a

59. Nygård (n53), paras. 28-30.

60. Case 127/75 Bobie, ECLI:EU:C:1976:95, para. 3

61. Nygård (n53), para. 31 (producers/exporters); Orgacom (n6), para. 31, where, however, in fact producers and importers were not at the same marketing stage.

62. Case 132/80 United Foods, ECLI:EU:C:1981:87, para. 39; Nygård (n53), para. 33.

63. Case C-72/92 Scharbatke, ECLI:EU:C:1993:858, paras. 14, 15; Nygård (n53), paras. 37, 38; unclear Orgacom (n6), para. 36, where there had been a tax reduction in the exporting country.

64. See, for example, Case C-517/04 Koornstra, ECLI:EU:C:2006:375, paras. 18, 23-25: purchase by a (quasi-public) Dutch organisation of shrimp sieves and peelers and their installation and maintenance, financed by Dutch fishermen regardless of whether they landed and processed their catch in the Netherlands, or in other Member States.

65. Essent Netwerk Noord (n4), para. 55 (electricity).

66. Scharbatke (n63), para. 10; Essent Netwerk Noord (n4), para. 42; Lubrizol France (n22), paras. 46, 47 diffuse and diverse range of economic activities sometime in the future.

For this comparison of the respective burdens and their alleviation, the benefits bestowed on the domestic product over the reference period (typically, the tax year) must be translated into monetary figures, whether or not these benefits were financial or intangible (such as advertising by a national agency financed out of the revenue of the dues). ${ }^{67}$ Any criteria other than financial equivalents, such as the nature, scope or indispensable character of those advantages, would not be sufficiently objective. ${ }^{68}$ In the case of a total set-off, the levy has the salient feature of customs duties and charges having equivalent effect, namely that it targets specifically imports or exports, to the exclusion of domestically made products that are also marketed domestically. ${ }^{69}$ If the tax is only partially offset, there will be discriminatory taxation under Article 110, 1st paragraph instead. ${ }^{70}$

\section{8 'Regardless of Its Mode of Application, the Designation of the Revenue From It, or the Absence of a Protective Effect'}

The last element in the Court's definition of a charge having equivalent effect to a customs duty is meant to forestall any attempts by the Member State at evading the prohibition. This is why, in particular, the modalities of the levying of the duty are irrelevant. More specifically, it does not matter whether a charge is demanded at the frontier or is instead imposed following the goods' further delivery along the supply chain. The duty can be levied at the frontier, or anywhere inland at the wholesale or retail level of trade. What is decisive is not when or where but why it is levied, namely with a view to past importation or future exportation. ${ }^{71}$

67. See, for example, the advertising activities of the 'Centrale Marketingagentur für die deutsche Landwirtschaft' (CMA) that were the subjectmatter of the proceedings in Case C-325/00 Commission v. Germany, ECLI:EU:C:2002:633, para. 25.

68. Case C-28/96 Fricarnes, ECLI:EU:C:1997:412, para. 27; Case C-347/95 Facenda Pública v. UCAL, ECLI:EU:C:1997:411, para. 25

69. Lubrizol France (n22), para. 37.

70. Joined Cases 78-83/90 Cie Commerciale del'Ouest ECLI:EU:C: 1992:118, para. 27: contributions by importers of petroleum fuels into France to a French agency promoting energy savings and the rational use of energy; Koornstra (n64), paras. 19, 20; most recently, PetrotelLukoil (n22), para. 24. For the modalities of the reimbursement by the Member State of the excessive part of the taxation, see Case C-255/00 Grundig Italiana (no.2), ECLI:EU:C:2002:525, paras. 33-41. Where a company has not, in the form of higher prices, passed on to the consumer the amount of the unlawful charge but has otherwise absorbed the charge, although national law provided for such passing on, the company can still demand reimbursement from the national authorities: Petrotel-Lukoil (n22), paras. 32-37.

71. Case C-272/95 Deutsches Milch-Kontor (no.2), ECLI:EU:C:1997:191, paras. $30,31,40$. 
The designation of the revenue is equally immaterial, but this question must not be confused with the above proviso re tax set-offs. At issue here are uses of the sums raised for purposes that are at first sight harmless, such as for social or cultural concerns. ${ }^{72}$ If a levy meets the criteria set out above, such benevolent purposes can still not save it from the prohibition in Article 30. To say it again, the Member States remain entirely free to finance social, cultural, and any other policies out of general taxation that is in keeping with Article 110. They must not, however, draw on imports or exports alone to this end. Likewise, it does not matter whether the Member State uses the revenue for state aid. This is a question to be assessed separately under Article 107 TFEU. The procedures to operationalise that provision are largely in the hands of the Commission. This does not, however, detract from the right of individuals to invoke the direct effect of the prohibition in Article 30.73

Finally, because the financial burden on the free movement of goods is decisive, no evidence of a decline in trade is required. ${ }^{74}$ This has a parallel in Article 101(1) TFEU: if an agreement, etc. has as its object (rather than merely as its effect) the restriction of trade, the Commission need not adduce evidence that such a restriction has occurred in fact; instead, a restriction can in those circumstances be present even where cross-border trade has increased..$^{75}$

\section{The Bigger Picture}

It is easy to take for granted the abolition of customs duties and charges having equivalent effect and the establishment of a customs union between the Member States. This early achievement has been in place for so long that it was overshadowed, soon after, by the unfolding of the other freedoms that is associated with judgements like Dassonville, Cassis de Dijon, van Binsbergen, van Wesemael, Walrave, to which could be added van Duyn, Ratti, Harz, Marshall, Francovich, and many others from the 1970 s to the 2010s. While the developments in these areas are ongoing and even accelerating, the law regarding customs duties and charges having equivalent effect is more or less still where it was by the mid-1970s.

72. Diamantarbeiders (n19), paras. 11/14; Mikhaïlidis (n8), para. 17 Orgacom (n6), para. 35; Lubrizol France (n22), para. 28

73. Cie Commcerciale del'Ouest (n70), paras. 32, 33; Case C-17/91 Lornoy, ECLI:EU:C:1992:514, paras. 28, 29; Nygård (n53), paras. 53, 62.

74. Statistical levy (n21), paras. 6, 10

75. Joined Cases 56 and 58/64 Consten \& Grundig v. Commission, ECLI:EU:C:1966:41, p341: 'The fact that an agreement encourages an increase, even a large one, in the volume of trade between states is not sufficient to exclude the possibility that the agreement may 'affect' such trade in the abovementioned manner'; p. 342: 'For the purpose of applying article [101(1)], there is no need to take account of the concrete effects of an agreement once it appears that it has as its object the prevention, restriction or distortion of competition.' The Court held likewise in Case 56/65 Société technique minière v. Maschinenbau UIm, ECLI:EU:C:1966:38, p. 249, last para.
Nevertheless, Articles 28-31 TFEU, as interpreted by the Court, anticipated the deep penetration of EU law into the law of the Member States that would become even more apparent in these later developments. The law on customs duties and charges having equivalent effect has attracted much less political controversy than the later developments in the area of free movement. Maybe that is because it came first, when the Member States and their public paid less attention or were more accepting. All the same, this penetration was necessary to remove as far as possible the 'frontiers', in the formulation of Article 26(2) TFEU, that are in the way of the free movement of goods. Any exceptions, any reservations for the Member States, translate into less free trade.

Evidence for this proposition comes from the provisions of GATT, ${ }^{76}$ to which reference has occasionally been made above. The permissibility of charges for controls adopted unilaterally by Member States is but one example. To this can be added any other charges having equivalent effect to customs duties (to borrow the language of the Treaty), as long as they precede or coincide with the release of a product onto the market. What is more, while the charge may be insubstantial, its levying will entail administrative burdens, and both hindrances can accumulate, as the Court observed right from the start of its jurisprudence.

The intrusion of another legal order into the domestic law of the Member States is in this way the price of the benefits that all derive from freer trade. The Member States' freedom to legislate as they please - their sovereignty - is partially (origin-neutral taxation always remains legal) traded for a larger and more open market. One might consider sovereignty and free trade incommensurable: what price to put on legislative freedom? Nevertheless, the question whether the trade-off is worthwhile will arise, whether or not it can be answered in exact figures, or only instinctively. It is safe to predict that the experience of the UK after Brexit will provide the Member States with clearer criteria to work this out, each for itself.

\section{Conclusion}

The jurisprudence of the Court of Justice regarding the prohibition of customs duties and charges having equivalent effect between Member States is well established. The Court has held a steady line since the late 1960s, which it continually refined in subsequent decades. Few questions are controversial: one may wonder whether the element of 'consideration for services actually rendered' is an indispensable part of the assessment or whether financial burdens occasioned by the crossing of the lines between internal subdivisions of a Member State ought to be assessed under Article 110 rather than under Article 30. These are, however, side issues that 
are more of doctrinal interest than of practical relevance. The creation and maintenance of a free trade area and a customs union between Member States was successfully accomplished and maintained.

The free movement of goods in its financial aspect was thus the first of the four freedoms of the internal market to be realised. Nevertheless, the internal market is about to shrink in its geographical extent. The United Kingdom left the EU on 31 January 2020, with the transition period under its Withdrawal Agreement ending on 31 December $2020 .{ }^{77}$ It is comforting to reflect that the provisions on the free movement of goods will retain much of their relevance even after Brexit. No matter whether there will eventually be a trade deal, once British goods have reached the market in one Member State, they can from there be traded freely into any other Member State, Article 28(2) and 29 TFEU. That was the situation before the UK joined (which is when the facts of Dassonville played). ${ }^{78}$ It will be true again after the UK has left. 